\title{
The impacts of interaction of audit litigation and ownership structure on audit quality
}

\author{
Riyadh Jassim AL Abdullah' and Mawih Kareem AL Ani ${ }^{2 *}$ (1)
}

\begin{abstract}
This study examines the impact of the interactions of audit litigation and ownership structure on audit quality by Big 4 and non-Big 4 audit firms in Oman. This study uses modified audit opinion as proxies for audit quality, binary variable for audit litigation and percentage of shares owned by large shareholders and minority shareholders (consisting of Arab [non-GCC] shareholders) for ownership structure. The study uses size, risk, types of activity and ages of the firms as control variables. For the analysis and explanation of results descriptive statistics, correlation, regression techniques and T-test are used. Based on a sample of 107 listed companies on Muscat Securities Market (MSM) for 2013-2017, we find that audit litigation has a significant impact on audit quality for Big 4 audit firms, but not for non-Big 4 audit firms. Also, the results indicate that there is no difference between Big 4 and non-Big 4 audit firms as far as litigation risk is concerned.
\end{abstract}

Keywords: Audit litigation, Audit quality, Ownership structure, Emerging economy, Oman

JEL Classification: M40, M42, G32

\section{Introduction}

Since 2005, the Capital Market Authority (CMA) which is responsible for the control of the audit firms in Oman issued warning letters to some audit firms, suspended one audit firm from conducting audits for firms regulated by CMA for one year and suspended eight audit firms for three months due to their violations of articles of the Omani Commercial Companies. Thus, the credibility of audited financial statements issued by audit firms remains questionable. Since 2000, the number of litigations related to audit issues has increased to 32,000 [4]. Out of these, 2250 cases were against the Big 4 firms. Prior researches $[2,22,25,29,54]$ assess the impact of audit litigation and ownership structure separately on audit quality, rather than exploring the combined impact of both the audit litigation and ownership structure on audit quality. This study fills the gap in the literature by evaluating audit litigations and auditees' ownership structures on audit quality. ${ }^{1}$

\footnotetext{
*Correspondence: mawih@duedu.om

${ }^{2}$ Accounting Department, Dhofar University, Dhofar, Oman

Full list of author information is available at the end of the article
}

Ownership structure is defined in terms of size of shareholders as well as the identity or nationality. Muscat Securities Market (MSM) is totally regulated by CMA. There are two groups of shareholders in terms of size: large shareholders which include three types of investor's nationalities; Omani, Arab-GCC (Gulf Cooperation Council) and foreign and the minority shareholders group which includes only one type of investor that is Arab non-GCC. Large shareholders are those who hold a sizable fraction of all voting shares in the firms, whereas the minority shareholders are those who hold a less sizable fraction of these shares.

Omani data were used for the evaluation due to accessibility of data and for filling the gap in literature on the impact of audit litigations and auditees' ownership structure on audit quality of Big 4 or non-Big 4. Data related to ownership structure and audit quality were collected from MSM reports, while the data of audit litigation were retrieved from CMA reports. All these data were officially from CMA.

\footnotetext{
${ }^{1}$ GCC stands for Gulf Cooperation Council. This Council consists of six countries: Saudi Arabia, Kuwait, Qatar, United Arab Emirates, Bahrain and Oman.
} 
The findings of this study contribute to the literature on audit litigation and audit quality in several ways. First, to the best of our knowledge, this is the first study that examines interactions between audit litigation and ownership structure on audit quality in the Omani environment and elsewhere. Prior studies [2, $22,25,29,54]$ tend to assess the association between audit litigation and audit quality separately from the associations between auditees' ownership structure and audit quality. These studies use two variables: ownership structure as an independent variable and audit quality as a dependent variable, and they report positive or negative results for the two variables. Another group of prior studies that discuss the association between ownership structure and audit quality is moderated by only one factor such as earnings management [32], audit fees [27] or risk [52]. On the other hand, one of the most important issues regarding audit litigation is the relationship between audit litigation and audit quality. Most of scientific works here concluded that there is a significant relationship between audit litigation and audit quality [12, 20, 26, 35, 49, 51]. Second, with the imposition of the requirement by CMA that Omani firms must comply with International Financial Reporting Standards (IFRS) and International Auditing Standards (IAS) and increasing global trades and business transactions, both auditors and auditees face a constant challenge of meeting the reporting and auditing expectations. Accordingly, an increasing number of audit litigations have been motivating local audit firms to ensure quality in compliance with the international rules and regulations. We use this opportunity to investigate the extent of the impact of both audit litigation and auditees' ownership structure on meeting the increasing challenge on disclosure and compliance. Third, our findings contribute to the literature on Big 4 audit firms. Although there is wide evidence in the literature that Big 4 audit firms provide a high level of audit quality, this paper extends this line of research by examining the effect of audit litigation on audit quality.

The paper's structure is given as follows. In "Audit litigation: with focus on Oman" section elaborates audit litigations in general and in Oman in particular. In "Literature review and hypotheses development" section is about the relevant literature and development of hypotheses. Section four is about the methodology. In "Empirical analysis" and "Results and discussion" sections, respectively, present the empirical analysis and discuss the results. Conclusion, limitations of the current paper and suggestions for further research are included in "Conclusion" section.

\section{Audit litigation: with focus on Oman}

In general, there are two types of litigations against audit firms; the first is carried out by government authority or any authorized audit associations and the second is carried out by audit clients. This study is within the domain of the first type.

Litigation against an audit firm can arise from carrying out audit services in companies having publicly or privately traded securities. Furthermore, litigation against an audit firm covers audit services (e.g., audit of financial statements) as well as non-audit services (e.g., preparation of tax report, assurance services, consultancy services, etc.). Audit litigation may also arise from violations of laws such as company law, securities acts, contract law or/and any other regulations [6].

In the relevant literature, the term "audit litigation risk" is used to refer to the possibility that legal action is executed due to dissatisfaction with an auditor's or audit firm's actions, inaction, products, services and/or other activity [19]. According to Kim and Skinner [31], the litigation risk is the risk of securities class action lawsuits, as opposed to the risk of legal action brought by government agencies/departments. This study embraces this distinction and, accordingly, defines the audit litigation risk as the class action lawsuit, as opposed to the risk of legal action brought about by government agencies in the context of Oman, particularly, i.e., the legal action carried out by the Ministry of Commerce and Industry and CMA in Oman.

There are many possible direct and indirect impacts of the litigations cases in Oman on the auditor, auditor's behavior, audit firm, audit profession, auditees and financial community in general. Damaged reputation of auditor and audit firms, significant monetary costs associated with litigation and declarations of bankruptcy of audit firms are examples of direct impacts of litigation related to audit activities $[6,44]$. Changes in ownership structure, indirect monetary costs associated with auditor litigation such as investments to enhance quality control, significant negative market reaction to companies that were audited by litigation audit firm and effects related to new client acceptance where the litigation audit firms are less likely to receive new engagements are examples of indirect effects of auditor litigation [28].

Unfortunately, there is no formal statistics about the litigation cases against the auditors in the Arab countries or GCC countries including Oman.

Oman CMA through Inspection and Examination Department is an authorized agency that is responsible for controlling the audit firms working in Oman. CMA states that "CMA emphasizes that all audit firms must comply with the applicable laws and regulations to enhance professionalism, confidence and credibility." 
The CMA issued around six warning letters and suspension decisions related to accounting and auditing issues against some audit firms in Oman: both Big 4 and nonBig 4 since 2005. These warning letters and suspension decisions became audit litigations due to violating the IFRS and IASs. It must be emphasized that CMA has the required judicial power.

A significant limitation is related to data on litigious cases in Oman. Court lawsuits and settlements between auditors and clients are generally unavailable because cases are often resolved privately without public disclosure of the agreed settlements. Information on lawsuits is available for only 6 of the unknown total lawsuits.

Up to date, in Oman, there are many lawsuit cases but only six cases were carried out against some audit firms. The cases covered Big 4 audit firms and non-Big 4 audit firms and are related to accounting and auditing issues. The total clients (i.e., auditees) of these two types of audit firms are 32 listed companies out of 107 on MSM. Fifteen out of 32 auditees are clients of the non-Big 4 audit firms and 17 are clients of Big 4 audit firms. The remaining numbers, i.e., 75 companies, were audited by non-Big 4 and Big 4 audit firms that were not subjected to litigation cases.

In Oman as in elsewhere, auditing plays a crucial role in adding credibility to financial statements. However, the accountancy and audit affairs are not under the control of well-established profession. Government agencies have the full responsibility in this regard. There are two governmental agencies that govern this profession: CMA and the Ministry of Commerce and Industry. However, there is no independent agency regulating and controlling the external auditors. In 2016, the Association of Chartered Accountants of Oman was established but only allowed offering consultancy role and providing support to the audit profession. The regulatory framework consists of three sources of regulations to organize the profession. These are the Commercial Company Law No. 4 issued in 1974 and its amendments, Accounting and Auditing law through Royal Decree No 77 was issued in 1986 followed by a number of amendments and CMA Code of Corporate Governance Regulation was issued in 2002 followed by a number of amendments. These laws and regulations include many general rules of auditing such as independence, registration, auditor rights and obligations, formulation of audit committees, penalties, auditor's qualifications and the relationships between external auditing and internal auditing.

There are some important facts related to the auditing in Oman. First, according to Article 111 of Omani Company Law no. 4 issued in 1974, all joint-stock and limited liability companies must be subjected to external auditing by one local or foreign qualified and recognized auditor. Audit committee of the clients is given a vital role in recruiting the auditor. Second, in the Omani audit market, there are 19 audit firms and offices recognized by CMA and registered in the Ministry of Commerce and Industry and grouped into three types of audit firms: Big 4 audit firms, non-Big 4 audit firms and local audit offices. By the end of 2017, 73\% of listed companies were audited by Big 4 audit firms and $27 \%$ were audited by non-Big 4 audit firms. Third, the auditors of listed companies should be appointed by the board of directors and shareholders on a yearly basis, and rotated each four-year period. Fourth, the financial statements of listed companies are prepared according to IFRS and audited according to IASs. Fifth, it is allowed to the audit firm to provide only three types of non-audit services, namely audit-related services, taxation advisory services and investigation of matters arriving from auditor's findings or observations to by their clients, and it should be reviewed and approved by the audit committee. Finally, the audit market in Oman is very small and the competition between auditor firms is very high [5].

\section{Literature review and hypotheses development Audit quality and audit litigation}

Most of the researches in the area of audit quality used DeAngelo's [13] definition of audit quality. According to DeAngelo (12: 186), "the audit quality is defined as the probability that a misstatement in the accounts of the audited entity is discovered and reported by the auditor as assessed by the market." Practically, prior studies used different proxies to measure the audit quality. The common proxies are Big and non-big auditor (audit firm size), discretionary accruals, audit fees, accrual quality, goingconcern or modified opinions, meet or beat the quarterly earnings target and audit fees [43]. El Deeb and Ramadan [16] provide a comprehensive discussion with respect to audit quality proxies that are used in the literature. Like Chen et al. [10] and Wong et al. [51] and due to availability of information, we will measure the audit quality by the issuance of modified audit opinions. On average, within the period of this study in Oman, the Big 4 audit firms issued around 58 (54\%) modified audit reports for 107 listed companies, while around (21) 20\% modified audit reports were issued by non-Big 4 audit firms, which means that the total modified report is 79 . Within the first group, 9 modified audit reports were issued by litigated Big 4 and 10 by litigated non-Big 4 audit firms, while 49 and 11 reports issued by non-litigated non-Big 4 .

The issue of audit quality is one of the most attractive and controversial in both emerging and developed markets. There are many empirical evidences that the low level of audit quality is one of the main reasons for 
financial, corporate and auditing scandals [48], Sayyar et al. [45]. On the other hand, high level of audit quality can improve some firm characteristics such as performance and financial reporting as well as audit characteristics such as independence of the auditor and the level of audit fees [45].

Because audit quality is an important theme in auditing; many researchers discuss it in their studies. Empirically, more attention is given to the association between audit quality and audit fees [1], audit committee [36], ownership structure [29], audit firm size and earnings management [16, 32], firm performance [45], non-audit fees [50] and corporate governance [22].

Recently, the discussion of the association between audit quality and audit litigation is increased. Lennox and Li [35] conclude that the audit quality will improve following litigation against the auditor. Catanach et al. [8] find that Big 4 auditors are less likely to accept new audit engagements relative to small auditors related to clients with high-risk litigation. Badertscher et al. [6] find that higher litigation risk is arising from public equity ownership (governmental ownership). Baldauf et al. [7] find a positive association between risk aversion of auditor and audit quality, which means that recruiting a risk-averse auditor will improve the audit quality. Franz et al. [20] suggested that audit litigation is a measure of audit quality and therefore the market interprets audit litigation as an indicator of a low level of audit quality. Czerney et al. [12] found that higher level of litigation will improve the quality of financial reports because the auditor will increase the audit efforts to improve the audit quality.

These results are consistent with the argument that potential clients perceive litigation against audit firms as an indicator of lower audit quality. This has many adverse effects such as decrease in the audit fees, decrease in the new engagements of new clients, decrease in the bargaining power of the auditor and decrease in the financial reporting quality of the client's financial statement. Therefore, the first hypothesis is:

H\#1 There is a statistically negative relationship between audit litigation and audit quality.

\section{Ownership structure, audit quality and audit litigation}

One of the most important topics in accounting, auditing and finance is ownership structure and how it changes or behaves based on certain circumstances. In the area of auditing, there are many papers that discuss the relationship between ownership structure and audit characteristics such as audit firm size, audit fees and independence of auditor. However, this area is not addressed by even single paper whether covering the Omani or GCC countries.

Because most of the prior studies use different measures of ownership structure (such as large shareholders, managerial ownership and family ownership), some results illustrate either single or mixed relationship between ownership and audit characteristics. It is very rare that prior studies are congruent in their results. There are always mixed results. For example, Lennox [34] examines the relationship between audit firm size and management ownership structure and finds negative relationship, which means that the probability of recruiting a large audit firm is lower as management ownership increases. Kasai [27] finds a negative relationship between audit fees and institutional ownership structure. Basically, the reason for this negative relationship is that the audit client prefers to save audit fees rather than increase the audit quality. On the other hand, in the multi-different results studies, the mixed results are common. For example, Zureigat [54] finds positive relationship between audit firm size as a proxy for audit quality and foreign and institutional ownership structures. On the other hand, the relationship between audit quality and ownership structure is found to be negative. Also, Nelson and Mohamed-Rusdi [39] find significant positive relationship between audit fees and firms with larger foreign ownership and government ownership but find no relationship between audit fees and managerial ownership. The appropriate interpretation for this positive relationship is that in some business environment the audit quality is more important for foreign investors who are ready to pay more fees for audit quality. Also, Eshghalizadeh [17] and Ali and Lesage [3] find mixed results. For example, Ali and Lesage [3] find three types of results: a negative relationship between audit fees and government shareholdings; a positive relationship between audit fees and institutional shareholdings; and no relationship between audit fees and family shareholdings. The different results can be justified because each group in the ownership structure has different objectives and power. Family shareholders focus on achieving short-term profits rather than on long term objectives [9]. Therefore, family ownership causes companies to pay lower fees for the audit process. In contrast, higher audit fees are acceptable by institutional and foreign shareholders because they believe that this sends positive signal to the market about the quality of their performance in order to attract more investments [3]. El Deeb and Abdel Megeid [15] find that audit firm size in terms of Big 4 audit firm and non-Big 4 audit firm reflecting an audit quality plays a vital role in enhancing capital structure decisions. In particular, they find that auditor type as one of proxies of corporate governance has positive association with 
capital structure decisions (e.g., reduction in financial leverage).

It seems that the prior literature examines many types of ownership structure individually and collectively. Ownership structures such as large shareholder, foreign ownership, institutional ownership, family ownership, block ownership, managerial ownership, employee's ownership, government ownership, retail ownership and domestic ownership are exhaustively examined. Ownership structure in Omani firms is characterized by "stable shareholders." The largest institutional and single shareholders do typically exceed a $5 \%$ of shares, but only some individual shareholders and institutional shareholders own around $30 \%$ or more of shares. According to the classification by MSM, the structure of ownership of listed companies in MSM is different. This structure is defined based on one general criterion that is the ownership identity/nationality of investor, Omani or non-Omani. Omani investor is all Omani individuals or institutions who can buy or sell shares in MSM. Non-Omani investor has three clusters: the investor from GCC countries that have the same characteristics of Omani investors, the Arab investor from outside GCC countries and the last one being the foreign investor. Foreign investor is defined as percentage share held by companies which are incorporated inside Omani or those foreign investors inside Oman. GCC investors are those investors or institutions in the other GCC countries outside Oman, and Arab non-GCC investors are those investors or institutions from all other Arab countries.

In the area of audit quality, prior studies examine the relationship between ownership structure as an independent variable and audit quality as a dependent variable. These studies find positive and/or negative effects of ownership structure on some variables such as audit quality, audit fees and audit firm size. On the other hand, audit litigation or lawsuit is only discussed in relation to many audit characteristics such as audit fees and audit firm size.

In this study, the Omani shareholders, shareholders from GCC countries and foreign shareholders are considered as the large shareholders. This is because these three types of shareholders have the majority percentage of shares in all listed companies on MSM since they own around $96 \%$ of the shares. In addition, the GCC countries shareholders have the same rights as Omani shareholders. The Arab non-GCC countries shareholders are considered as minority shareholders because they own around $4 \%$ by the end of 2017 . Based on the above discussion, the second hypothesis is:

H\#2 There is a statistically positive relationship between large shareholder ownership and audit quality.
According to [41], the minority shareholders are not interested in controlling the company and making managerial strategic decisions. Nurdin et al. [40] concluded that minority shareholders have negative effect on the optimal level of leverage because they slow the adjustment process toward the optimal level of leverage. Accordingly, the third hypothesis is:

H\#3 There is no statistical relationship between minority ownership and audit quality.

Audit litigation is likely to damage both audit characteristics such as auditor's reputation and audit quality and client characteristics such as firm value, performance and ownership structure. The ownership structure as defined in this study consists of two groups of shareholders; large shareholders and minority shareholders. Large shareholders are an important mechanism for corporate governance which may affect the audit litigation. There are two perspectives for the relationship between audit litigations and large shareholders. The positive perspective refers to the case that the large shareholders increase their percentage of shares that they own to get more control and power to prevent the audit litigations in the future. For example, Fan et al. [19: 15] indicate that the "litigation auditors have competing incentives regarding new client acceptance decisions following a lawsuit." Also, large shareholders are providers of capital and they possess the ability to reduce cost of capital, increase share price and influence strategic decisions. Therefore, they might increase their ownership to protect their capital and to exercise more control and power [41]. On the other hand, large shareholders can take some actions against litigation auditor to avoid possible losses in the future. For example, Skinner and Srinivasan [47] discuss some negative consequences for audit litigations. First, around one quarter of the clients left the auditor after the audit litigation was announced. Second, future clients may believe that the litigation auditors provide lower audit quality and, accordingly, they become less willing to engage with those auditors compared with non-litigation auditors. This perspective is justified by small shareholders who are ready to shift to those companies audited by non-litigation auditors if they expect that the performance of the company will decrease because of the audit litigations.

There is not a known prior study on the extent of interactions between audit litigation and ownership on audit quality. According to Hay et al. [24] as cited by Kouaib and Jarboui [32], the existing and potential large shareholders are requesting auditors who offer better audit and non-audit services to increase the quality of financial reporting of the companies to protect their benefits 
Table 1 Number of clients of audit litigation and non-litigations audit firms

\begin{tabular}{|c|c|c|c|c|c|c|c|}
\hline \multirow[t]{2}{*}{ Sector } & \multicolumn{3}{|c|}{ Big 4 audit firms } & \multicolumn{3}{|c|}{ Non-Big 4 audit firms } & \multirow[t]{2}{*}{ Total } \\
\hline & $\begin{array}{l}\text { Clients of } \\
\text { litigation }\end{array}$ & $\begin{array}{l}\text { Clients of non- } \\
\text { litigation }\end{array}$ & Total & $\begin{array}{l}\text { Clients of } \\
\text { litigation }\end{array}$ & $\begin{array}{l}\text { Clients of non- } \\
\text { litigation }\end{array}$ & Total & \\
\hline Finance and banking & 8 & 19 & 27 & 1 & 3 & 4 & 31 \\
\hline Industrial & 6 & 17 & 23 & 13 & 5 & 18 & 41 \\
\hline Services & 3 & 25 & 28 & 1 & 6 & 7 & 35 \\
\hline Total & 17 & 61 & 78 & 15 & 14 & 29 & 107 \\
\hline
\end{tabular}

and to avoid the conflict of interest with the managers because of such conflict increase in case of ownership concentration [37]. Thus, large shareholders will be attracted by the companies which present financial statements audited by non-litigation auditors because this type of auditors reflects high level of audit quality [33]. On the other hand, large shareholders are holding high percentage of shares in their companies, which means that they can control the managers by using other control mechanisms (such as board of director, board committees and ownership structure) rather than resorting to external auditing [46]. Accordingly, the fourth hypothesis is:

H\#4 There is no statistical effect of the interaction between large shareholder ownership and audit litigation on audit quality.

Mustafa et al. [38] discuss the relationship between minority shareholders and audit quality and they conclude that the minority shareholders have motivation to increase audit quality. According to agency theory, minority shareholders have a feeling of high level of risk due to many reasons. They might feel that they do not access reliable accounting information; their investments are not protected because managers might not use the company's fund properly and there is the possibility of conflict of interest between them and both managers and large shareholders. This indicates that the minority shareholders need to mitigate and reduce all of the above-mentioned risks through using non-litigation auditors. Accordingly, the fifth hypothesis is

H\#5 There is no statistical effect of interaction of minority shareholder ownership and audit litigation on audit quality.

\section{Methods}

\section{Sample and data}

This study attempts to investigate the effect of interaction of audit litigation and ownership structure on audit quality for listed companies on the MSM. The total number of companies listed on the MSM at the end of the 2017 was 107 distributed among three sectors: banking and finance companies (31), industrial companies (41) and service companies (35). Since 2005, six audit litigation cases were diagnosed by CMA related to accounting and auditing issues. The study sample consists of all 107 companies which equal 535 observations. Data about ownership structure and audit firms were collected from the annual reports for the listed companies and report of the MSM. In this report, $73 \%$ of listed companies are audited by Big 4 audit firms and 27\% are audited by non-Big 4 audit firms by the end of 2017.

For each audit litigation case, we have four groups; clients of litigation Big 4 audit firms and clients of nonlitigation Big 4 audit firms, clients of litigation non-Big 4 audit firms and clients of non-litigation non-Big 4 audit firms. Tables 1 and 2 show the statistics for each group.

Based on Table 1 , there are $17(17 / 78=22 \%)$ audit clients audited by litigation Big 4 audit firms and 15 $(15 / 29=52 \%)$ audit clients audited by litigation non-Big 4 audit firms. For better clarity and differentiation, this study will make four types of analysis:

- The effect of audit litigation on audit quality moderated by ownership structure of the clients of litigation Big 4 audit firms.

- The effect of audit litigation on audit quality moderated by ownership structure of the clients of litigation non-Big 4 audit firms.

- Establishing the differences between the clients of litigation and clients of non-litigation of Big 4 audit firms.

- Establishing the differences between the clients of litigation and clients of non-litigation of non-Big 4 audit firms. 
Table 2 Variables and definitions

\begin{tabular}{|c|c|c|}
\hline Variable & Code & Definition \\
\hline \multicolumn{3}{|l|}{ Moderating variables } \\
\hline Large shareholder & LS1 & The percentage of shares (\%) owned by Omani investors \\
\hline Large shareholder & LS2 & The percentage of shares (\%) owned by GCC countries investors \\
\hline Large shareholder & LS3 & The percentage of shares (\%) owned by Foreign investors \\
\hline Minority shareholders & MS & The percentage of shares (\%) owned by Arab non-GCC invertors \\
\hline \multicolumn{3}{|l|}{ Independent variable } \\
\hline Audit litigations & ALs & Binary variable, 1 if audit litigation and otherwise 0 \\
\hline \multicolumn{3}{|l|}{ Dependent variable } \\
\hline Audit quality & AQ & Binary variable, 1 if modified audit report and otherwise 0 \\
\hline \multicolumn{3}{|l|}{ Control variables } \\
\hline Size of the company & $\mathrm{S}$ & Algorithm of total assets \\
\hline Age of the company & AG & Algorithm of years \\
\hline Leverage & $\mathrm{R}$ & Debt-to-equity ratio \\
\hline Activity of the clients & $A C$ & $\begin{array}{l}\text { Type of sector that the company belongs to it, dummy vari- } \\
\text { ables: Banking and finance (1), industrial (2) and services (3) }\end{array}$ \\
\hline
\end{tabular}

\section{Definition of the variables}

The study uses a regression approach to control for the effect of the ownership structure on audit quality under the audit litigations. In this study, we model ownership structure rates as a function of audit quality under the audit litigation. There are four groups of variables: dependent variable, independent variables, moderating variable and control variables.

The moderating variable is the ownership structure which is measured by four concentrations as per the classification of MSM:

Large shareholders $\quad(\mathrm{LS} 1)=$ Omani $\quad$ ownership (OMO).

Large shareholders $(\mathrm{LS} 2)=\mathrm{GCC}$ countries ownership (GCCO).

Large shareholders (LS3) = Foreign ownership (FO). Minority shareholders $(\mathrm{MS})=$ Arab $\quad$ (non-GCC) ownership (AO).

The independent variable is Audit Litigations (ALs) against the audit firms which is measured by binary variable, 1 if audit litigation and otherwise 0 .

The dependent variable is the audit quality which is measured by the modified audit report issued by audit firm as a binary variable, 1 if modified audit report and otherwise 0 .

The third group of variables is control variables. These variables are added in the regression model that are not of interest in themselves but are included to reduce the aggregate bias for every additional relevant variable that we include in the models. These variables are kept constant so the changes in other variables can be observed more easily. The control variables help to define the relationship between the independent and dependent variable in the model [21]. Our choice of control variables follows prior research. In this study, we use four control variables; age, size, risk and activity of the client because most of the studies have employed these variables in their models.

According to Collier et al. [11], age and size of the firm are determinants of risk. They conclude that the younger firms and smaller firms face many threats which create many types of risk. In the area of auditing, we expect that companies are more (less) likely to be litigious if they are younger (older). Also, we expect that companies are more (less) likely to be litigious if they are smaller (larger) in size. In this study, age of the company is measured by the number of years since date of establishment (algorithm), while size of the company is measured by algorithm of total assets.

Leverage is the third control variable which refers to the financial strength of the client firms [6]. Risk of the company is measured by debt-to-equity ratio. We control for risk or leverage because the audit litigation is borne by the auditor of the client.

Finally, we control for activity of the clients because the audit litigations are different between the clients across the sectors in the MSM. The activity of the clients is measured by dummy variable: banking and finance (1), industrial (2) and service (3).

According to the types of analysis and variables, the models are as follows:
Model\#1: The effect of interaction of audit litigation and ownership structure on audit quality for the cli- ents of Big 4 audit firms. 
Table 3 Descriptive statistics

\begin{tabular}{llllll}
\hline \multicolumn{2}{c}{ Variables } & N & Minimum & Maximum & Mean \\
& Statistics & Statistics & Statistics & Statistics & Statistics \\
\hline LS1 & 107 & 0.01 & 1.00 & 0.7782 & 0.24751 \\
LS2 & 107 & 0.00 & 0.99 & 0.1421 & 0.21830 \\
LS3 & 107 & 0.00 & 0.65 & 0.0750 & 0.14573 \\
MS & 107 & 0.00 & 0.17 & 0.0040 & 0.01927 \\
R & 107 & 0.00 & 1.70 & 0.3095 & 0.29872 \\
AG & 107 & 4.00 & 45.00 & 25.3832 & 9.99589 \\
S & 107 & 2.24 & 7.00 & 4.6509 & 0.81814 \\
AC & 107 & 1.00 & 3.00 & 2.0374 & 0.78818 \\
ALS & 107 & 0.00 & 1.00 & 0.3084 & 0.46401 \\
AQ & 107 & 0.00 & 1.00 & 0.7383 & 0.44162 \\
\hline
\end{tabular}

In this model, we have two types of clients. The first is clients of litigation of Big 4 audit firms, and the second is the clients of non-litigation of Big 4 audit firms. Therefore, the model is: the rate of audit litigations is around 22\% during the period of the study. Table 3 also reports descriptive statistics for the control variables: age, risk, activity and size of the firm. For example, the mean value of age of these companies is 24 years, which means that they have good experiences in the business. The mean value of risk indicates that these companies are funded by debts with $31 \%$ and owner equity provides $69 \%$.

Table 3 allows us to observe, in a descending order, that the mean value of Omani large shareholders (LS1) is around 78\%, GCC countries large shareholders (LS2) is around 14\%, then foreign shareholders (LS3) is around $7.5 \%$ and finally Arab shareholders (MS) is $0.4 \%$. This means that in all listed companies, Omani, GCC courtiers and foreign investors (large shareholders) own a very high percentage of shares against minority shareholders (Arab non-GCC) which give these three groups more capital concentration, control and power. The mean of risk is positive, $30.95 \%$, which means that the owner equity is the main source for the listed com-

$$
\begin{aligned}
\text { AQbig4 }=\alpha \text { it } & +\beta \text { it }+\beta_{1} \text { LS1it }+\beta_{2} \text { LS2 it }+\beta_{3} \text { LS3it }+\beta_{4} \text { MSit } \\
& +\beta_{5} \text { ALsit }+\beta_{6} \text { LS1it } * \text { ALsit }+\beta_{7} \text { LS2it } * \text { ALsit }+\beta_{8} \text { LS3it } * \text { ALsit } \\
& +\beta_{9} \text { MSit } * \text { ALsit }+\beta_{10} \text { AGit }+\beta_{11} \text { Sit }+\beta_{12} \text { Rit }+\beta_{13} \text { ACit }+\in \text { it. }
\end{aligned}
$$

Model\#2: The effect of interaction of audit litigation and ownership structure on audit quality for the clients of non-Big 4 audit firms.

In this model, we also have two types of clients. The first is clients of litigation of non-Big 4 audit firms, and the second is the clients of non-litigation of non-Big 4 audit firms. Therefore, the model is: panies, and there are a limited number of Omani companies which are highly in debt. The mean of activity, 2.0374 , indicates that the high number of listed companies is in the industrial sector which is equal to $68 \%$ of total listed companies. The result shows that the majority of the listed companies (73.83\%) have modified audit reports, which means that the audit quality is

$$
\begin{aligned}
\text { AQnonbig4 }=\alpha \text { it } & +\beta \text { it }+\beta_{1} \text { LS1it }+\beta_{2} \text { LS } 2 \text { it }+\beta_{3} \text { LS3it }+\beta_{4} \text { MSit } \\
& +\beta_{5} \text { ALsit }+\beta_{6} \text { LS1it } * \text { ALsit }+\beta_{7} \text { LS } 2 \text { it } * \text { ALsit }+\beta_{8} \text { LS3it } * \text { ALsit } \\
& +\beta_{9} \text { MSit } * \text { ALsit }+\beta_{10} \text { AGit }+\beta_{11} \text { Sit }+\beta_{12} \text { Rit }+\beta_{13} \text { ACit }+\in \text { it. }
\end{aligned}
$$

In both models, we add the following variables:

$\alpha_{\text {it }}=$ constant. $\beta=$ beta. $\varepsilon_{\text {it }}=$ error term. $i$ th $=$ firm. $t$ th $=$ period.$t$ th $=$ period.

\section{Empirical analysis}

\section{Descriptive statistics}

Table 3 provides descriptive statistics for the sample used to estimate the models. The mean value of dependent variable (LS1) indicates that Omani ownership rate is $78 \%$ of total of shares in the companies audited by Big 4 audit firms, while the other three ownership structures represent around $22 \%$. The mean value of audit litigation by Big 4 audit firms is $21.79 \%$, which means high. There are around $31 \%$ of audit clients audited by litigation audit firms during the period of the study. The means of both the size and age show that all listed companies have quite enough experience to deal with risk.

\section{Multicollinearity test and correlation matrix}

The multicollinearity is a computational difficulty that appears when two or more independent variables are highly correlated. From Table 4, the autocorrelation refers only to positive correlation between audit litigation and size of companies and negative correlation between size and minority shareholders but it only is weakly correlated with each other. 
Table 4 Multicollinearity test and correlation matrix $(N=107)$

\begin{tabular}{|c|c|c|c|c|c|c|c|c|c|c|}
\hline & LS1 & LS2 & LS3 & MS & $\mathbf{R}$ & AG & $S$ & $A C$ & ALs & $A Q$ \\
\hline LS1 & 1 & & & & & & & & & \\
\hline LS2 & 0.021 & 1 & & & & & & & & \\
\hline LS3 & -0.156 & -0.108 & 1 & & & & & & & \\
\hline MS & 0.037 & -0.074 & -0.090 & 1 & & & & & & \\
\hline$R$ & -0.049 & 0.080 & -0.038 & 0.028 & 1 & & & & & \\
\hline$A G$ & 0.161 & -0.188 & 0.015 & -0.002 & -0.126 & 1 & & & & \\
\hline$S$ & -0.128 & 0.065 & 0.145 & $-0.194^{*}$ & -0.075 & -0.141 & 1 & & & \\
\hline$A C$ & 0.174 & -0.086 & -0.179 & 0.089 & -0.166 & 0.048 & -0.096 & 1 & & \\
\hline ALs & 0.021 & -0.059 & 0.064 & -0.108 & -0.158 & -0.062 & $0.198^{*}$ & -0.161 & 1 & \\
\hline $\mathrm{AQ}$ & 0.093 & -0.126 & 0.064 & $-0.241^{*}$ & 0.126 & -0.176 & -0.011 & 0.001 & $-0.201^{*}$ & 1 \\
\hline
\end{tabular}

${ }^{*}$ Correlation is significant at the 0.05 level (2-tailed)

Table 5 Regression results between ALs and AQ

\begin{tabular}{lllll}
\hline Model & & B & T-Value & Sig \\
\hline 1 & (Constant) & 0.777 & 2.925 & 0.004 \\
& R & 0.002 & 0.700 & 0.486 \\
& AG & -0.161 & -1.828 & 0.070 \\
& S & 0.053 & 0.083 & 0.934 \\
& AC & -0.010 & -0.107 & 0.915 \\
& ALs & -0.204 & -2.102 & 0.038 \\
\hline
\end{tabular}

R-square $=13.7 \%, F$-value $=4.477, P$-value $=0.038$

Dependent variable $=A Q$

On the other hand, there are negative significant correlations between audit quality (AQ) and both minority shareholders (MS) and audit litigation (ALs) at 0.05 . These results indicated that if the percentage of MS increases, the AQ decreases and vice versa and if the percentage of ALs increases, the AQ decreases and vice versa.

According to Hair et al. [23], the presence of high correlations (generally 0.80 and above) is the first indicator of substantial multicollinearity. As shown in Table 4, the correlations between the independent variables including control variable are low and below 0.80 . This result indicates that no multicollinearity problem occurs for all the study variables.

\section{Results and discussion}

\section{Model 1: Big 4 audit firms' litigation and non-litigation} Audit litigation and audit quality (Testing Hypothesis\#1)

The first hypothesis is regarding the relationship between audit litigation and audit quality. Table 5 indicates that this relationship is significant at 0.05 and the audit litigation has negative impact on audit quality $(F$-value $=4.477$, $P$-value $=0.038<0.05, t$-statistic $=-2.102)$.

As for the coefficient of the audit litigations (ALs), it is negative $(-0.204)$ and significant $(P$-value $=0.038)$.
Table 6 Regression results between ownership and AQ

\begin{tabular}{lllll}
\hline Model & & B & T-value & Sig \\
\hline 2 & (Constant) & 2.631 & 15.004 & 0.000 \\
& LS1 & 0.032 & 0.980 & 0.330 \\
& LS2 & $-\mathbf{0 . 4 9 7}$ & -3.032 & 0.003 \\
LS3 & 0.157 & 0.980 & 0.330 \\
MS & $-\mathbf{0 . 2 8 8}$ & -2.312 & 0.023 \\
R & 0.097 & 1.522 & 0.133 \\
AG & -0.232 & -2.515 & 0.014 \\
S & -0.053 & -0.549 & 0.585 \\
AC & 0.047 & 0.815 & 0.418 \\
\hline
\end{tabular}

$R^{2}=16.8 \%, F$-value $=7.557, P$-value $=0.001$

Dependent variable $=\mathrm{AQ}$

Therefore, a negative and significant impact of audit litigations on audit quality is clearly discerned. $R^{2}$ is $13.7 \%$, which means that the model explains $13.7 \%$ of variation in AQ. This result agrees with that of Lennox and Li [34]. This is consistent with the first hypothesis that the audit litigation of Big 4 audit firms has negative consequences on the audit quality.

Also, Table 5 allows us to conclude that control variables do not have an effect on the audit quality, which means that the association between audit litigations and audit quality does not change because of size, risk, age and sector and the audit litigations have this effect on audit quality regardless of the control variables. For example, the audit quality decreases if there is any audit litigation against the auditor for large size client as well for low size client.

\section{Ownership structure and audit quality (Testing hypotheses\#2 and 3)}

Table 6 shows the results of hypotheses 2 and 3 for Big 4 audit firms: 
Table 7 Interaction between LS, MS and ALs on AQ

\begin{tabular}{lllll}
\hline Model & & B & T-value & Sig \\
\hline 1 & (Constant) & 0.800 & 14.730 & 0.000 \\
& LS1ALs & 0.015 & 0.085 & 0.932 \\
& LS2ALs & -0.904 & -1.691 & 0.035 \\
& LS3ALs & -0.483 & -0.836 & 0.406 \\
& MSALS & -0.287 & -2.375 & 0.020
\end{tabular}

$R^{2}=13.2 \%, F$-value $=2.763, P$-value $=0.034$

Dependent variable $=A Q$

According to the results of Table 6, LS2 and MS have significant negative effect on audit quality at 0.05 as the coefficients of LS2 and MS are $(-0.497)$ and $(-0.288)$, respectively. $R^{2}$ is $16.8 \%$, which means that the model explains $16.8 \%$ of variation in AQ which is more than the previous $R^{2}$ between ALs and AQ. These results indicate that any increase in GCC countries shareholders ownership as large shareholders and minority shareholders inversely effect on audit quality. We think that if the GCC countries shareholders ownership and minority shareholders are increased, the audit quality decreases because these two categorizes have very less control on the managers and auditors. Therefore, they might use litigated auditor to audit their financial statements. Also, for control variables group, there is only one variable with impact on the audit quality, that is, age of the firm. As the age of a company increases, the audit quality decreases. This result is consistent with the reality in Oman where companies that have more age tend to use service of litigation audit firms.

Model 1: Big 4 audit firms' litigation and non-litigation: interaction of ownership structure and audit litigation on audit quality (Testing Hypotheses \#4 and 5)

In this subsection, the effect of interaction of ownership structure and audit litigation on audit quality is tested. Table 7 indicates that GCC ownership (LS2) and minority ownership (MS) structures have inverse significant relationship with audit quality at 0.05 as the coefficients of LS2 and MS are (-0.904) and (-0.287), respectively. The other two interactions between ownership structures (Omani and Foreign) and audit litigation do not have any effect on audit quality. $R^{2}$ is $13.2 \%$, which means that the model of interaction explains $13.2 \%$ of variation in $\mathrm{AQ}$. Of these findings, it is noted that in the Omani context, the type of an auditor (i.e., Big 4 audit litigation or non-litigation) from the perspective of Omani and GCC investors does not have impact on audit quality. On the other hand, from the perspective of Arab non-GCC and foreign investors it appears that they do have significant impact on audit quality.
Table 8 T-test results

\begin{tabular}{|c|c|c|c|c|}
\hline & \multicolumn{2}{|c|}{$\begin{array}{l}\text { Levene's } \\
\text { test for } \\
\text { equality of } \\
\text { variances } \\
\end{array}$} & \multicolumn{2}{|c|}{$\begin{array}{l}\text { t-test for equality of } \\
\text { means }\end{array}$} \\
\hline & $F$ & Sig & df & $\begin{array}{l}\text { Sig. } \\
\text { (2-tailed) }\end{array}$ \\
\hline $\begin{array}{l}\text { AQ equal variances assumed } \\
\text { Equal variances not assumed }\end{array}$ & 9.057 & 0.104 & $\begin{array}{l}2.11676 \\
1.86224\end{array}$ & $\begin{array}{l}0.038 \\
0.075\end{array}$ \\
\hline
\end{tabular}

\section{Model 1: Further analysis}

In order to find any differences between litigated Big 4 and non-litigated Big 4 regarding audit quality, we use $t$-test for two samples. Table 8 shows that there are no differences between litigation Big 4 and non-litigation Big 4 regarding audit quality because the value in the "Sig. (2-tailed)" (0.104) is more than 0.05. This means there is no difference in the audit quality for the litigation Big 4 and non-litigation Big 4 audit firms. Both types of firm consider audit quality as an important criterion for their audit work and reputation.

\section{Discussion of results of Model 1}

According to the results of model 1, the audit litigation has inverse impact on audit quality in the Big 4 audit firms' sample. This means the audit quality is a sensitive issue for the Big 4 audit firms and their clients where the audit quality decreases if the size of audit litigation against Big 4 audit firms increases. The Big 4 audit firms are more risk averse to the damage of their reputation from financial and economic scandals and audit failures. This result is consistent with the findings of Eshleman and Guo [18] who find that Big 4 audit firms do perform higher audit quality, which means they are more likely to issue going-concern reports. Big 4 audit firms have many advantages such as high audit fees, large share market and more new engagements every year, high level of bargaining power with clients and authorized auditing associations and high level of audit quality and financial reporting quality of the client's financial statements. These results suggest that Big 4 audit firms are likely to lose most of these advantages in case of audit litigation, especially in the highly competitive audit market like that of Oman. For example, Fan et al. [19] conclude that litigation audit firms have fewer new engagements following the litigation. Another example is introduced by Hay et al. [24] about audit fees who find that audit fees for litigated auditor are significantly lower than those of non-litigated auditor. Therefore, the audit quality and audit litigations have a priority for 4 big audit firms in that they tend to keep their reputation and audit quality at a high level. There are many evidences that these 
Table 9 Chi-square tests and symmetric measures (ALs and AQ)

\begin{tabular}{lllll}
\hline & Value & Df & Asymp. Sig & Approx. Sig \\
\hline Pearson Chi-square & 0.514 & 28 & 0.474 & \\
Nominal by nominal Phi & -0.133 & & & 0.474 \\
Cramer's V & 0.133 & & & 0.474 \\
No. of valid cases & 29 & & & \\
\hline
\end{tabular}

${ }^{*}$ Correlation is significant at the 0.05 level (2-tailed)

issues are important for Big 4 audit firms. For example, Ernst \& Young has created the position of vice chairman of quality and risk management. PricewaterhouseCoopers $(\mathrm{PwC})$ has established a grading system similar to the one used by credit-rating agencies such as Moody's and Standard and Poor's [53]. Also, clients under the auditing of an auditor who engages in audit litigation there would be at a higher risk of losing some of their advantages such as a decrease in the market fair value of shares.

Empirical evidence shows that there is statistically negative significant effect of large shareholders No. 2 (GCC countries shareholders) and minority shareholders (Arab non-GCC) on audit quality of firms audited by Big 4. Also, there is statistically no significant effect of large shareholders No. 1 and 3 (GCC countries shareholders) and minority shareholders (Arab non-GCC) on audit quality. These results do not provide incentives to auditors to deliver high-quality audit and, accordingly, constrain their behavior to avoid any audit litigation. It seems that Big 4 audit firms are unable to deliver audit quality in the presence of Omani and foreign shareholders ownership. We believe that this situation is justified because the audit market in Oman is small, number of competitive audit firms is less few, and the auditing is governed by public agencies which will reduce the effect of ownership structure on audit quality.

Model 2: Non-Big 4 audit firms' litigation and non-litigation Since the sample of non-Big 4 audit firms is small $(N=29)$, it is probable that data do not follow the normal distribution. For this reason, we will use the nonparametric tests to examine the hypotheses of this model.

\section{Audit litigation and audit quality}

Table 9 shows that the value of Chi-square is 0.514 and $P$-value is 0.474 . This result tells us that there is no statistically significant relationship between audit litigation and audit quality, which means both audit litigation and audit quality are independent and audit quality is not affected by audit litigation. Furthermore, in order to test the strength of the relationship, we use Phi and Cramer's $\mathrm{V}$ and it seems that the strength of relationship between the variables is very weak.
Table 10 Chi-square tests and symmetric measures (Ownership structure and audit quality)

\begin{tabular}{lllll}
\hline & \multicolumn{3}{l}{ Pearson Chi-square } & \\
\cline { 2 - 5 } & LS1 & LS2 & LS3 & MS \\
\hline Value & 15.651 & 6.319 & 10.228 & 3.770 \\
Df & 15 & 11 & 9 & 3 \\
Asymp. Sig. (2-sided) & 0.406 & 0.851 & 0.322 & 0.287 \\
Phi & 0.735 & 0.467 & 0.594 & 0.361 \\
Cramer's V & 0.735 & 0.467 & 0.594 & 0.361 \\
No. of valid cases & 29 & 29 & 29 & 29 \\
\hline
\end{tabular}

Table 11 Chi-square tests and symmetric measures

\begin{tabular}{lllll}
\hline & \multicolumn{4}{l}{ Pearson Chi-square } \\
\cline { 2 - 5 } & LS1 & LS2 & LS3 & MS \\
\hline Value & 12.313 & 9.870 & 8.175 & 2.328 \\
Df & 15 & 11 & 9 & 3 \\
Asymp. Sig. (2-sided) & 0.655 & 0542 & 0.517 & 0.507 \\
Phi & 0.652 & 0.583 & 0.531 & 0.283 \\
Cramer's V & 0.652 & 0.583 & 0.531 & 0.283 \\
No. of valid cases & 29 & 29 & 29 & 29 \\
\hline
\end{tabular}

\section{Ownership structure and audit quality}

Based on Table 10, it seems that Sig. of Chi-square of all ownership structures is greater than 0.05 , which means that there is no statistically significant relationship between ownership structures and audit quality. In this case, both ownership structures and audit quality are independent and audit quality is not affected by ownership structures. Furthermore, to test the strength of this relationship, we use Phi and Cramer's V. The result of the test indicates there is a very weak relationship.

\section{Interaction between ownership structure and audit litigation on audit quality}

Based on Table 11, it seems that Sig. of Chi-square of all interactions is greater than 0.05 , which means that there is no statistically significant relationship between interactions and audit quality. In this case, both interactions and audit quality are independent and audit quality is not affected by interaction between ownership structure and audit litigation. Again, in order to test the strength of this relationship, we use Phi and Cramer's V. There is still a very weak relationship.

\section{Further analysis}

In order to find any differences between litigation nonBig 4 and non-litigation non-Big 4 regarding audit 
Table 12 Test statistics

\begin{tabular}{lr}
\hline & AQ \\
\hline Mann-Whitney U & 92.500 \\
Wilcoxon W & 212.500 \\
Z & -0.704 \\
Asymp. Sig. (2-tailed) & 0.481 \\
Exact Sig. [2*(1-tailed Sig.)] & $0.591^{\text {a }}$
\end{tabular}

Grouping variable: ALs

${ }^{a}$ Not corrected for ties

Table 13 T-test for comparison between litigation Big 4 versus litigation non-Big 4 audit firms

\begin{tabular}{lllllc}
\hline & Bignon & N & Mean & SD & SE mean \\
\hline AQ & 1.00 & 17 & 0.5556 & 0.51131 & 0.12052 \\
& 0.00 & 15 & 0.6667 & 0.48795 & 0.12599 \\
$\begin{array}{l}\text { Levene's test } \\
\text { for equality of } \\
\text { variances }\end{array}$ & $\begin{array}{c}F=1.455, \text { Sig }=0.237, t \text {-statistics }=-0.635,-0.637, \\
\text { Sig.tailed })=0.530,0.529\end{array}$ & \\
\hline
\end{tabular}

quality, we use Mann-Whitney test. Results of Table 12 indicate that there are no statistically significant differences between litigated non-Big 4 and non-litigated nonBig 4 audit firms $(U=92.5, P=0.592)$.

\section{Further Analysis: litigation Big 4 vs. litigation non-Big 4 audit firms}

We further examine whether there are any differences between litigation Big 4 and litigation non-Big 4 audit firms regarding the audit quality. Table 13 presents the results of this comparison. The sample is restricted to litigation Big 4 and non-Big 4 audit firms. The results indicate that there are no statistically significant differences (Levene's test for equality of variances: $F$-value $=1.455$, $P$-value $=0.237)$ between the two samples regarding audit quality, which means that the audit quality is an important issue for both Big 4 and non-Big 4 audit firms.

According to Czerney et al. [12], many studies indicate that Big 4 audit firms provide relatively higher audit quality than the other audit firms such as non-Big 4 audit firms. For example, compared to non-Big 4 audit firms, Big 4 audit firms are associated with less litigation because of the Big 4 audit firms are more conservative and sensitive regarding their reputation.

One of the most important issues in the dichotomy of Big 4 and non-Big 4 audit firms is the differences in company characteristics between Big 4 and non-Big 4 clients. In this study, we address one difference between them, that is, audit litigations.

An important motivation for Big 4 firms when providing high-quality audit is that their "deep pockets" do not subject them to greater litigation risk [14, 18, 42]. The size of the damage award in judgments against Big 4 audit firms can also be larger for the same reason [30]. As a result, investors are more likely to sue Big 4 audit firms, along with the involved company and management for the recovery of some of their losses. A different but related argument is that large auditors have stronger incentives to provide high quality audits because they have more invaluable reputations.

\section{Conclusion}

This study examines how the audit litigation affects the audit quality moderated by the ownership structure. In this study, two models were tested: the audit litigation and audit quality moderated by ownership structure of clients audited by Big 4 audit firm and non-Big 4 audit firm. Regarding the first model, our results show that the audit quality is a sensitive issue for the Big 4 audit firms and their clients where the audit quality will decrease if the size of audit litigation against Big 4 audit firms is increased. The result based on hypothesis testing provides insignificant effect of audit litigation on the ownership structure of Omani companies listed on MSM for both clients. While most of prior studies conclude that there is a significant relationship between ownership structure and audit quality, audit fees and other audit characteristics, the result of this study is different. In the first model, the effect of audit litigation on the ownership structure of clients audited by Big 4 audit firms was tested. The result of the test indicates that there is no significant effect of audit litigation on the ownership structure. This means that ownership structure of listed Omani companies does not change because of the audit litigations against the Big 4 audit firm. Specifically, the ownership structure of clients has weaker sensitivity toward the audit litigations of both Big 4 and non-Big 4 audit firms. Thus, the evidence of this study suggests that audit litigations are significantly less likely to cause any change in the ownership structure.

In the second model, the results show that there is no statistically significant relationship between audit litigation and audit quality. Also, the results tell us that there is no statistically significant relationship between ownership structures and audit quality. The effect of the interaction between ownership structure and audit litigation on audit quality is very weak.

Finally, the results indicate that there is no statistically difference between the two samples (Big 4 and non-Big 4) regarding audit quality, which means that the audit quality is an important issue for both Big 4 and non-Big 4 audit firms.

There are certain limitations in the data gathering and analysis processes. First, the time series examined 
is only 5 years (2013-2017) which is a short period. Second, due to non-availability of all necessary annual reports and other related data, we use only one proxy to measure the audit quality, that is, the modified audit report. There are other proxies such as audit fees, audit risk and discretionary accruals which are not used in this study. Third, Oman as an emerging economy has very few number of audit litigations because the audit market is very small and it is governed by the governmental agencies. Fourth, we use the taxonomy of ownership structure as declared by MSM. However, other structures (family ownership, institutional ownership and managerial ownership) are not used.

Those limits constitute a motivation for further research. We suggest extending the study period to include more audit litigation cases. This will allow getting more robust results. Also, we suggest that other audit quality proxies can be used such as audit fees and discretionary accruals in addition to modified audit report to get more comprehensive results. Since 2016, the Association of Chartered Accountants of Oman was created as a potential player in the audit market. Here, we expect that this relationship will take some roles and responsibilities from the government to organize the audit market. In this regard, we predict that the number of audit litigations will increase which allows us to conduct more studies in Oman. Also, in the future studies, all GCC countries shall be included in such studies because these countries have almost the same audit market characteristics and ownership structures. We suggest that future researches should study the effect of audit litigation on audit quality moderated by other types of ownership structures such as family ownership, institutional ownership and managerial ownership to see how the different structure can effect on the audit quality.

\begin{abstract}
Abbreviations
CMA: Capital Market Authority; GCC: Gulf Cooperation Council; MSM: Muscat Securities Market; IFRS: International Financial Reporting Standards; IAS: International Auditing Standards; OMO: Omani ownership; LS2: large shareholders; GCCO: GCC countries ownership; LS3: large shareholders; FO: foreign ownership; MS: minority shareholders; AO: Arab (non-GCC) ownership; ALs: audit litigations; $A Q$ : audit quality; S: size of the company; AG0: age of the company; $\mathrm{R}$ : leverage; AC: activity of the clients.
\end{abstract}

\section{Acknowledgements}

Not applicable.

\section{Authors' contributions}

MA reviewed the literature and analyzed, interpreted and discussed the results. He is the only contributor in writing the manuscript. RJAA read, revised and approved the final manuscript.

\section{Funding}

There is no source of funding.

\section{Availability of data and materials}

The datasets generated and/or analyzed during the current study are available in the Muscat Securities Market Web site repository, www.msm.gov.com

\section{Declarations}

Competing interests

The authors declare that they have no competing interests.

\section{Author details}

${ }^{1}$ Accounting Department, Bayan University, Baghdad, Iraq. ${ }^{2}$ Accounting Department, Dhofar University, Dhofar, Oman.

Received: 9 December 2020 Accepted: 13 April 2021 Published: 9 June 2021

\section{References}

1. Abdul-Rahman OA, Benjamin AO, Olayinka OH (2017) Effect of audit fees on audit quality: evidence from cement manufacturing companies in Nigeria. Eur J Account Audit Finance Res 5(1):6-17

2. Al Qadasi A, Abidin S (2018) The effectiveness of internal corporate governance and audit quality: the role of ownership concentrationMalaysian evidence. Corp Gov 18(2):233-253. https://doi.org/10.1108/ CG-02-2017-0043

3. Ali CB, Lesage C (2013) Audit pricing and nature of controlling shareholders: evidence from France. China J Account Res 6(1):21-34. https://doi. org/10.1016/..cjar.2012.08.002

4. Audit Analytics (2019) https://www.auditanalytics.com/contact?subject= Risk

5. Baatwah SR (2016) Audit tenure and financial reporting in Oman: does rotation affect the quality? Risk Gov Control Financial Mark Inst 6(3):16-27

6. Badertscher B, Jorgensen B, Katz S, Kinney W Jr (2014) Public equity and audit pricing in the United States. J Account Res 52(2):303-339

7. Baldauf J, Pummerer E, Steller M (2012) Audit quality, litigation and risk aversion-An analytical analysis of the influence of risk aversion on audit quality. All Innsbruck University, Austria

8. Catanach A, Irving J, Williams S, Walker P (2011) An ex post examination of auditor resignations. Account Horiz 25(2):267-283

9. Charbel S, Elie B, Georges S (2013) Impact of family involvement in ownership management and direction on financial performance of the Lebanese firms. Int Strateg Manag Rev 1(1-2):30-41

10. Chen CJP, Chen S, Su X (2001) Profitability regulation, earnings management, and modified audit opinions: evidence from China. Audit J Pract 20(2):9-30. https://doi.org/10.2308/aud.2001.20.2.9

11. Collier BL, Haughwout AF, Kunreuther HC, Michel-Kerjan EO, Stewart MA (2017) Firms' management of infrequent shocks. NBER Working Paper No. 22612. NBER Program(s): Public Economics

12. Czerney K, Lisic L, Wu B, Zhang J (2019) Big 4 auditors, litigation risk, and disclosure tone. Working paper, University of Nebraska, Virginia Tech, and University of Minnesota. https://papers.ssrn.com/sol3/papers.cfm?abstr act_id $=3351230$

13. DeAngelo LE (1981) Auditor size and auditor quality. J Account Econ 3(3):183-199

14. Dye R (1993) Auditing standards, legal liability, and auditor wealth. J Polit Econ 101(5):887-914

15. El Deeb MS, Sobhy NA (2017) An exploration of corporate social responsibility disclosure determinants, corporate governance and capital structure in the Egyptian stock exchange market. Egyp Account Rev 6:1-44

16. El Deeb MS, Ramadan M (2020) The impact of financial distress, firm size, and audit quality on earnings' management evidence from companies listed in the Egyptian stock exchange. Alexandria J Account Res 4(3):1-48

17. Eshghalizadeh A (2014) Study the relationship between audit fees by ownership structure of accepted companies in Tehran Stock Exchange. Appl Math Eng Manag Technol 2(4):521-527

18. Eshleman JD, Guo P (2014) Do Big 4 auditors provide higher audit quality after controlling for the endogenous choice of auditor? Audit J Pract Theory 33(4):197-219 
19. Fan Y, Li, C, Nagarajan N (2015) Auditor litigation, audit office pricing and client acceptance. Paper presented in 2015 Auditing Section Midyear Conference and Doctoral Consortium. January, 15-17, 2015: Miami, Florida, USA

20. Franz D, Crawford D, Johnson EN (1998) The impact of litigation against an audit firm on the market value of non litigating clients. J Account Audit Financ 13(2):117-134

21. Frölich M (2006) Non-parametric regression for binary dependent variables. Economet J 9(3):511-540

22. Gajevszky A (2014) Audit quality and corporate governance: evidence from the Bucharest Stock Exchange. J Econ Soc Dev 1(2):1-11

23. Hair JF, Black WC, Babin BJ, Anderson RE, Tatham RL (2006) Multivariate data analysis, 6th edn. Prentice Hall, New Jersey

24. Hay DC, Knechel WR, Wong N (2006) Audit fees: a meta-analysis of the effect of supply and demand attributes. Contemp Account Res 23(1):141-191

25. Imanzadeh P, Lalepour M (2013) The effect of corporate governance mechanisms on auditing quality of firms accepted in Tehran Stock Exchange. Appl Math Eng Manag Technol 1(3):58-63

26. Kang M, Lee H-Y, Mande V, Woo Y-S (2019) Audit firm attributes and auditor litigation risk. J Account Finance Business Stud 55(4):639-675

27. Kasai N (2014) Ownership structure, audit fees, and audit quality in Japan, Publisher: Shiga University, Faculty of Economics, Japan

28. Khalil S, Mazboudi M (2016) Client acceptance and engagement pricing following auditor resignations in family Firms. Audit A J Pract Theory 35(4):137-158. https://doi.org/10.2308/ajpt-51489

29. Khasharmeh $H$, Joseph N (2017) Does ownership structure affects audit quality: evidence from Bahrain? Global J Account Econ Finance 4(3):92-100

30. Khurana IK, Raman KK (2004) Litigation risk and the financial reporting credibility of Big4 versus non-Big 4 audits: evidence from Anglo-American countries. Account Rev 79(2):473-498

31. Kim ID, Skinner J (2012) Measuring securities litigation risk. J Account Econ 53(1-2):290-310. https://doi.org/10.1016/j.jacceco.2011.09.005

32. Kouaib A, Jarboui A (2014) External audit quality and ownership structure: interaction and impact on earnings management of industrial and commercial Tunisian sectors. J Econ Finance Adm Sci 19(37):78-89

33. Labelle R, Piot C (2003) Governance, audit et manipulations comptables. Revue du Financier 139:84-90

34. Lennox C (2005) Management ownership and audit firm size. Contemp Account Res 22(1):205-227

35. Lennox C, Li B (2014) Accounting misstatements following lawsuits against auditors. J Account Econ 57(1):58-75. https://doi.org/10.1016/j. jacceco.2013.10.002

36. Miko NU, Kamardin H (2015) Impact of audit committee and audit quality on preventing earnings management in the pre- and post-Nigerian Corporate Governance Code 2011. Procedia Soc Behav Sci 172:651-657. https://doi.org/10.1016/j.sbspro.2015.01.415

37. Mitra S, Hossain M, Deis DR (2007) The empirical relationship between ownership characteristics and audit fees. Rev Quant Finance Account 28(3):257-285. https://doi.org/10.1007/s11156-006-0014-7
38. Mustafa AS, Barwari AS, Mohammed NH (2018) Minority Shareholders'rights and audit quality: empirical evidence from Turkey. J Account Finance Audit Stud 4(4):27-44. https://doi.org/10.32602/jafas.2018.003

39. Nelson SP, Mohamed-Rusdi NF (2015) Ownership structures influence on audit fee. J Account Emerg Econ 5(4):457-478. https://doi.org/10.1108/ JAEE-05-2013-0027

40. Nurdin N, Kartini D, Fani M, Kaltum U (2016) Small Shareholders'intervention in the determination of Firm's Leverage. Int J Econ Commerce Manag IV 4:26-40

41. Oktorina M, Wedari LK (2015) An empirical investigation on ownership characteristics activities of the audit committee, and audit fees in companies listed on Indonesia stock exchange. Appl Finance Account 1(1):20-29

42. Palmrose ZV (1988) An analysis of auditor litigation and audit service quality. Account Rev 63(1):55-73

43. Rajgopal S, Suraj S, Zheng X (2020) Measuring audit quality, Working paper. https://ssrn.com/abstract=3504037 or https://doi.org/10.2139/ ssrn.3504037

44. Rothenberg NR (2020) Auditor reputation concerns, legal liability, and standards. Account Rev 95(3):371-391

45. Sayyar HR, Basiruddin S, Abdul Rasid Z, Elhabib MA (2015) The impact of audit quality on firm performance: evidence from Malaysia. J Adv Rev Sci Res 10(1):1-19

46. Sharma N (2017) Corporate governance mechanisms in India. Int J Adv Res Dev 2(5):132-137

47. Skinner DJ, Srinivasan S (2012) Audit quality and auditor reputation: evidence from Japan. Account Rev 87(5):1737-1765. https://doi.org/10. 2308/accr-50198

48. Soltani B (2014) The anatomy of corporate Fraud: a comparative analysis of high profile American and European corporate scandals. J Bus Ethics 120(2):251-274

49. Sun J, Guoping L (2011) Client-specific litigation risk and audit quality differentiation. Manag Audit J 26(4):300-316

50. Svanström T (2013) Non-audit services and audit quality: evidence from private firms. Eur Account Rev 22(2):337-366. https://doi.org/10.1080/ 09638180.2012 .706398

51. Wong RMK, Firth MA, Lo AWY (2018) The impact of litigation risk on the association between audit quality and auditor size: evidence from China. $J$ Int Financ Manag Acc 29(3):280-311

52. Yeung WH, Lento C (2018) Ownership structure, audit quality, board structure, and stock price crash risk: evidence from China. Global Finance Journal 37(2):1-24

53. YU DM (2007) The Effect of Big four Size on Audit quality, Unpublished Ph.D. Dissertation. Faculty of the Graduate School. University of Missouri-Columbia.

54. Zureigat QM (2011) The effect of ownership structure on audit quality: evidence from Jordan. Int J Bus Soc Sci 2(10):38-46

\section{Publisher's Note}

Springer Nature remains neutral with regard to jurisdictional claims in published maps and institutional affiliations. 